\title{
金属鉄を電子供与体として利用可能なメタン生成古細菌 (MPA)
} と硫酸塩還元菌（SRB）の共存による鉄腐食促進作用

\author{
伊藤公夫*, 若井暁**, 鶴丸博人**, 飯野隆夫**, \\ 森 浩二**, 内山 拓**, 三木 理*, 原山重明** \\ * 新日本製鐵株式会社 先端技術研究所 環境基盤研究部 \\ ** 独立行政法人製品評価技術基盤機構 (NITE) 生物遺伝資源開発部門
Iron Corrosion by Methane Producing Archaea (MPA) and Sulfate Reducing Bacteria (SRB) Utilizing Metallic Iron as an Electron Donor \\ Kimio Ito*, Satoshi Wakai**, Hirohito Tsurumaru**, Takao Iino**, \\ Koji Mori**, Taku Uchiyama**, Osamu Miki* and Shigeaki Harayama** \\ * Environment Research Lab., Advanced Technology Research Laboratories, Nippon Steel Corporation \\ ** Biotechnology Development Center, National Institute of Technology and Evaluation (NITE)
}

\begin{abstract}
Methane Producing Archaea (MPA), which could utilize metallic iron as an electron donor and $\mathrm{CO}_{2}$ as an electron acceptor and a carbon source, corroded an iron coupon severely in seawater medium under anaerobic condition $\left(\mathrm{N}_{2}(80 \%)+\mathrm{CO}_{2}(20 \%)\right)$. Main component of corrosion products by MPA was $\mathrm{FeCO}_{3}$. MPA corroded the iron coupon more severely when they coexisted with SRB which could also utilize metallic iron as an electron donor. Corrosion rate of the iron coupon by MPA + SRB was about 2.3 times higher than that by MPA only under anaerobic condition $\left(\mathrm{N}_{2}(80 \%)+\mathrm{CO}_{2}(20 \%)\right)$. Main component of corrosion products by $\mathrm{MPA}+\mathrm{SRB}$ was $\mathrm{FeCO}_{3}$ like that by MPA.

Corrosion rates of the iron coupon by MPA only, or MPA + SRB under anaerobic condition $\left(\mathrm{N}_{2}(80 \%)+\right.$ $\mathrm{CO}_{2}(20 \%)$ ) were higher than those under aerobic condition (Air) after the anaerobic corrosion experiments.

Therefore, corrosive effects on iron by MPA + SRB, which can utilize metallic iron as an electron donor, should be considered as cause of microbiologically influenced corrosion in the anaerobic corrosive environments like oil fields, where $\mathrm{CO}_{2}$ and $\mathrm{Cl}^{-}$are available.
\end{abstract}

Key words : methane producing archaea (MPA), sulfate reducing bacteria (SRB), iron, microbiologically influenced corrosion, anaerobe, crude oil, seawater, ferrous carbonate, $\mathrm{FeCO}_{3}$

1. 緒

言

酸素のない嫌気性環境には, メ夕ン生成古細菌 (Methane Producing Archaea; MPA) や硫酸塩還元菌 (Sulfate Reducing Bacteria; SRB) などの嫌気性微生物が 棲息している. SRB は中性条件で硫化水素イオン $\left(\mathrm{HS}^{-}\right)$ を発生して鉄を腐食し，黒色の硫化鉄（FeS）を生成す ることから, 古くから鉄腐食原因微生物として知られて いる。 しかし，もう一方の代表的な嫌気性微生物である MPA に関しては，鉄腐食との関係はほとんどわかって いない. MPA が発生するメタン $\left(\mathrm{CH}_{4}\right)$ には, SRB が発 生する硫化水素イオンのような鉄腐食性がないことか ら, これまで, MPA は鉄腐食原因微生物とはみなされ てこなかった。

我々は前報1) で，嫌気性条件 $\left(\mathrm{N}_{2}(80 \%)+\mathrm{CO}_{2}(20 \%)\right)$ の海水培地を用いて, 金属鉄を電子供与体, $\mathrm{CO}_{2}$ を電子 受容体かつ炭素源として利用可能な嫌気性微生物の集積 培養物を, 東北地区油井, 江戸川河口底泥, 九州地区原

\footnotetext{
* ㅈ293-8511 富津市新富 20-1（20-1, Shintomi, Futtsu, 293-8511 Japan)

** T292-0818 木更津市鎌足 2-5-8（2-5-8, Kamatari, Kisarazu, 2920818 Japan)
}

油タンク由来の環境試料から得て, それぞれの集積培養 物による鉄腐食への影響を調べて，九州地区原油タンク 底板残留スラッジ由来の集積培養物が激しい鉄腐食を起 こすことと, 主要な腐食生成物が炭酸鉄 $\left(\mathrm{FeCO}_{3}\right)$ であ ることを報告した。また，この九州地区原油タンク底板 残留スラッジ由来の集積培養物から, 金属鉄を電子供与 体として培養可能な鉄腐食性 MPA である Methanococcus maripaludis KA1 株を単離することに成功した22.ささらに, 同じ九州地区原油タンク底板残留スラッジから金属鉄を 電子供与体とする条件でも培養可能な SRB の MIC5-15 株を単離することにも成功した。

実際の嫌気性環境では MPA と SRB が単独で存在して いることは考えづらく, MPA と SRB は嫌気性環境の複 合微生物系で共存している可能性が考えられる。 そこで 本研究では, Methanococcus maripaludis KA1 株と MIC 5-15 株を用いて, 無菌の場合, MPA, SRB がそれぞれ単 独で存在する場合, MPA と SRB が共存する場合の鉄腐 食を，腐食試験により比較した。ささらに，SRBによる鉄 腐食では, 嫌気性環境で腐食した後, 引き続き空気にさ らされることによって，激しい鉄腐食が起こることが報 告されている3 ${ }^{3,4)}$. ほとんどの場合, 嫌気性環境におけ る鉄の微生物腐食は, 空気にさらされて人が腐食現場に 立ち入ることができるようになった条件で見つかる場合 が多い。このため, 嫌気性環境での微生物腐食と, その 
後の空気にさらされたことによる腐食影響の寄与程度が あいまいであった。そこで本研究では，嫌気性環境で 2 週間腐食試験を行った後, さらに 2 週間空気にさらした 条件に関しても腐食試験を行った。

\section{2. 実 験 方 法}

\section{1 腐食試験に用いた微生物}

\subsection{1 金属鉄を電子供与体として利用可能な MPA}

本研究では, 金属鉄を電子供与体として, $\mathrm{CO}_{2}$ を電子 受容体かつ炭素源として利用可能な MPA（Methanococcus maripaludis KA1 株)2）を用いた。

この MPA は，九州地区の原油タンクの底板に残留し たスラッジを試料として，純鉄（ $\mathrm{Fe}^{0} ）$ を電子供与体, $\mathrm{CO}_{2}$ を電子受容体かつ炭素源とする条件で, Uchiyama ら2)により単離された MPA である。

\section{1 .2 金属鉄を電子供与体として利用可能な SRB}

本研究では, 前記 MPA (Methanococcus maripaludis KA1 株）と同様に, 九州地区の原油タンクの底板に残留 したスラッジから単離した SRB（MIC 5-15 株）（Desulfovibrio dechloracetivoram (GenBank Accession Number AF230530）と 16S rRNA 遺伝子の塩基配列が 98.5\%相同） を用いた。この $\mathrm{SRB}$ は, 純鉄を電子供与体, $\mathrm{CO}_{2}$ を炭素 源とする条件で, 前記 MPA と同様に培養可能であるこ とを確認した SRBである.

\section{2 腐食試験および解析方法 \\ 2.2.1 嫌気性条件 $\left(\mathrm{N}_{2}(80 \%)+\mathrm{CO}_{2}(20 \%)\right)$ での腐食 試験}

腐食試験液には Widdel ら5）が報告し，Dinh ら6) が金 属鉄を電子供与体とする条件で嫌気性微生物の単離と腐 食試験に用いた海水培地の組成を参考に, Uchiyama ら ${ }^{2)}$ が改変して MPA による腐食試験に使用した海水培地を 用いた。この海水培地は $100 \mathrm{mM}$ Hepes 緩衝液（pH 7) を添加することにより $\mathrm{pH}$ を 7 に調製してある. 容積 70 $\mathrm{mL}$ のガラス容器（ブチルゴム栓付きバイアル瓶 V-50 ; 日電理化硝子) の底に純鉄（>99.5\% Fe）試験片（10× $10 \times 0.108 \mathrm{~mm})$ を 1 枚おき， $\mathrm{N}_{2}(80 \%)+\mathrm{CO}_{2}(20 \%)$ ガス で曝気して嫌気性条件にした上記腐食試験液を $20 \mathrm{~mL}$ 加 えて純鉄試験片を腐食試験液に浸漬した。ガラス容器内 の気相部にも $\mathrm{N}_{2}(80 \%)+\mathrm{CO}_{2}(20 \%)$ ガスを充填した状態 で，ブチルゴム栓とアルミキャップによりガラス容器を 密封した。微生物を接種する場合には, シリンジ針でゴ ム栓を貫通させることにより，空気にさらすことなく嫌 気的に微生物の培養液を $1 \mathrm{~mL}$ ずつ添加した。微生物の 培養液添加後, 緩やかにガラス容器を摇すって, 微生物

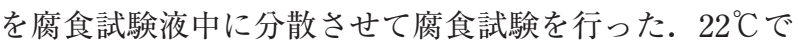
2 週間静置して腐食試験を行った。無菌の場合を対照区 (Control) として, SRB を単独接種した場合, MPAを単 独接種した場合，MPA と SRB を共に接種した場合， MPA を接種して 1 週間後に SRB を追加接種した場合, それぞれについて腐食試験を実施した。腐食試験を開始 してから 2 週間後, 腐食試験片を解析するため, 純窒素 ガス䨌囲気のグローブボックス中でガラス容器から試験 片を取り出し, 乾燥させた。乾燥した試験片を $1 / 2$ に切 断し，一方の試料は，断面観察用にクロスセクションポ
リッシャー（SM-09010, 日本電子）加工し, 断面をエネ ルギー分散型 $\mathrm{X}$ 線分析装置付き走査型電子顕微鏡 （SEM-EDS）（JSM7000F，日本電子）で観察し，C，O， $\mathrm{Mg}, \mathrm{Si}, \mathrm{P}, \mathrm{S}, \mathrm{Cl}, \mathrm{Ca}, \mathrm{Fe}$ の元素分布を解析した.

腐食試験終了後の試験片の SEM による断面の観察写 真を用いて，腐食生成物を除いた地鉄部分の残存板厚を 3 力所測り, その平均值を腐食試験終了時の試験片の残 存板厚とした。元の試験片の板厚 $(108 \mu \mathrm{m})$ と腐食試験 終了時の残存板厚の差を求め, 1 年間当たりの板厚減量 を腐食速度 (単位 mm/year) として計算した. 残存板厚 の測定值のばらつきに起因する腐食速度計算值のばらつ きを確認するため，標準偏差も計算した.

切断したもう一方の試験片試料は，X 線回折（XRD） （RINT1500，リガク）により腐食生成物の解析に用いた。 また，腐食試験終了後，試験液の $\mathrm{pH}$ を $\mathrm{pH}$ 電極により 測定した。

2.2.2 嫌気性条件 $\left(\mathrm{N}_{2}(80 \%)+\mathrm{CO}_{2}(20 \%)\right)$ での腐食 に引き続く好気性条件 (空気下) での腐食試験

前記 2.2.1 の嫌気条件 $\left(\mathrm{N}_{2}(80 \%)+\mathrm{CO}_{2}(20 \%)\right)$ におけ る腐食試験と同じ条件で, 同時並行して嫌気性条件での 純鉄試験片の腐食試験を行った. 2 週間経過後, フ夕を 開け, 内部の気相を空気に置換し, 試験液を緩やかに攪 拌して，試験液にも空気を溶存させた。気相部を空気と したまま再びフ夕をして水の蒸発を防いだ好気性条件 で，引き続き $22^{\circ} \mathrm{C} て ゙ ~ 2$ 週間静置して腐食試験を行った。 好気性条件で 2 週間（計 4 週間）経過後, 腐食試験片を 空気下で取りだし, 試験片を空気下で乾燥後, $1 / 2$ に切 断して, 前記 2.2.1 の方法と同様に, SEM-EDS, XRD に よる解析を行った。また，嫌気性条件に引き続く好気性 条件での腐食試験終了後については, 試験液の $\mathrm{pH}$ と酸 化還元電位 $(\mathrm{ORP})$ を $\mathrm{pH}$ 電極と白金電極を用いて測定し た。さらに，試験片を除いた腐食試験液を，眯濁物を含 めて均質化して採取し，塩酸を用いて鉄分を溶解後，ア スコルビン酸を用いて二価鉄に還元して，オルトフェナ ントロリン法により, 試験液の全鉄濃度を測定した。

\section{3. 結 果 と考 察}

\section{1 嫌気性条件 $\left(\mathrm{N}_{2}(80 \%)+\mathrm{CO}_{2}(20 \%)\right)$ での腐食試 験結果}

腐食試験を実施した純鉄試験片断面の SEM による観 察結果を Fig. 1(a)から (e)に，SEM-EDS による断面元素 分布の解析結果を Fig. 2 から 6 に示す。 また, 腐食生成 物の X 線回折結果を Table 1 に示す。無菌条件（Control） では, 純鉄試験片が腐食している様子は明確には観察で きなかった（Fig. 1(a)). SRB 単独で腐食させた場合に は，純鉄表面は黒色の平坦な被膜で覆われたが，この被 膜の下で腐食は進んでいなかった（Fig. 1(b))。この黒 色の被膜は腐食試験液を攪拌することにより容易に剥が れた. SEM-EDSにより，この黒色の被膜には Fe，S，C， $\mathrm{O}$ が検出された（Fig. 3). SRB による腐食生成物である ことから，この黒色の被膜には硫化鉄が含まれると考え られる．黑色の被膜の構成成分を調べるため，X 線回折 による解析も試みたが，黑色の被膜が非常に薄いためか, 地鉄の $\mathrm{Fe}$ のみしか明確なピークとして検出できなかった。

MPA 単独で腐食させた場合には，純鉄はほぼ均一に 
(a) Control

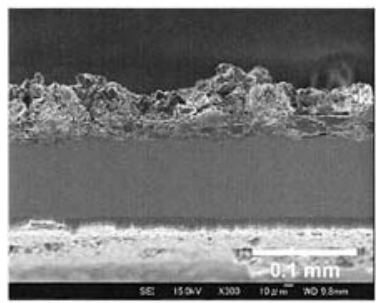

(c) MPA

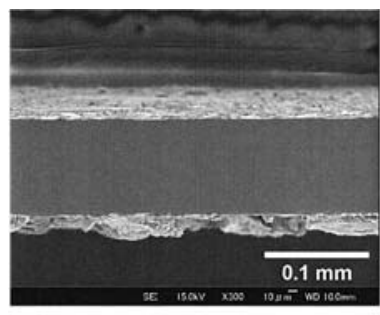

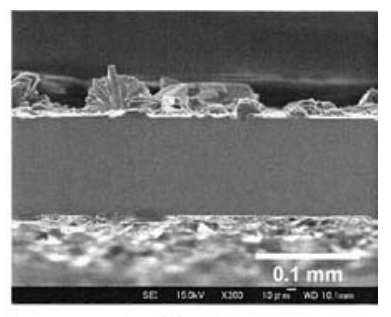

(b) SRB

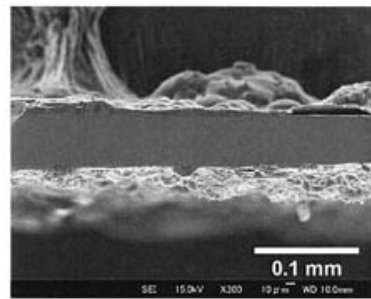

(d) $\mathrm{MPA}+\mathrm{SRB}$

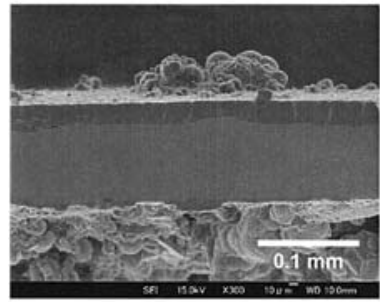

(e) MPA + SRB (SRB were inoculated one week later.)

Fig. 1 Cross Section Image of Iron Coupon by SEM.

全面腐食して, 表面は灰色の腐食生成物の厚い層で覆わ れた（Fig. 1(c)). SEM-EDSにより，腐食生成物には Fe, $\mathrm{O}, \mathrm{C}, \mathrm{Cl}, \mathrm{P}, \mathrm{Mg}$ が検出された (Fig. 4). 腐食生成物中 の元素の分布には以下の特徵があった. Fe, C, O は腐食
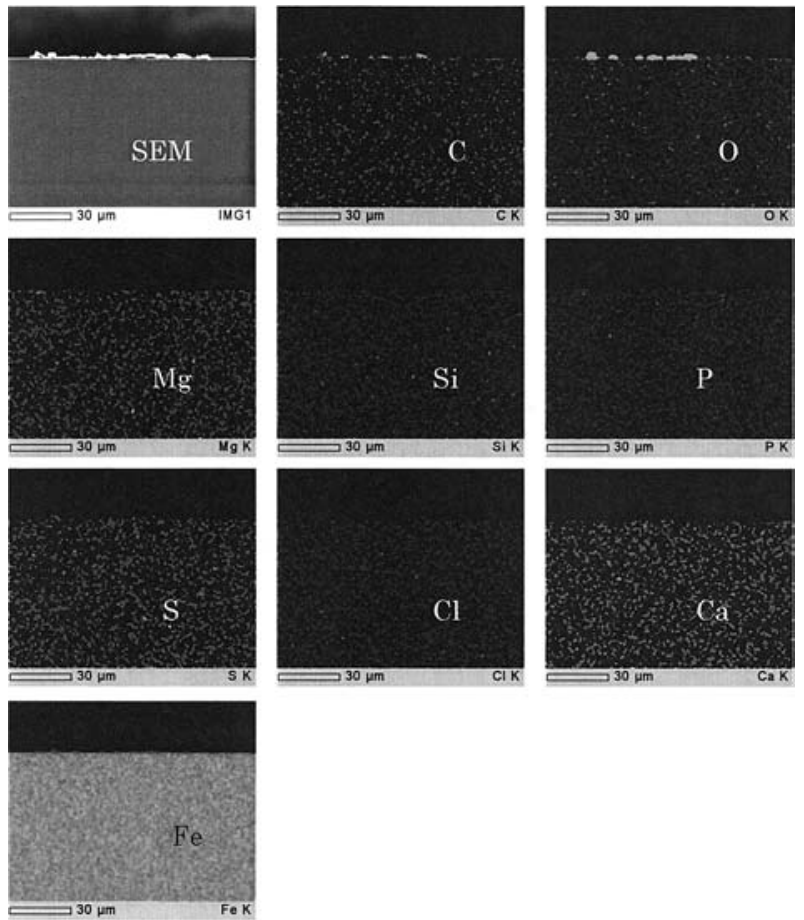

Fig. 2 Cross section image of iron coupon by SEM-EDS (Control).
生成物の地鉄と接する側に層状に検出された。 $\mathrm{Cl}$ は腐食 生成物と地鉄が接する境界部分に検出された。また， Fe， $\mathrm{O}, \mathrm{P}, \mathrm{Mg}$ が腐食生成物の上層に検出された。 $\mathrm{X}$ 線回折 では, MPA 単独で腐食させた場合の腐食生成物の主要 な構成成分として炭酸鉄 $\left(\mathrm{FeCO}_{3}\right)$ が同定された。したが って, SEM-EDS で腐食生成物の地鉄と接する下層に検 出された $\mathrm{Fe}, \mathrm{C}, \mathrm{O}$ は $\mathrm{FeCO}_{3}$ であると考えられる。 $\mathrm{FeCO}_{3}$ は炭酸ガス腐食の腐食生成物として知られてい る。 MPAの存在有無によって, $\mathrm{FeCO}_{3}$ 形成が強く影響 を受けることが明らかとなった。また，地鉄と接する部 分に $\mathrm{Cl}$ が検出されたことから, 地鉄表面に塩素イオン $\left(\mathrm{Cl}^{-}\right)$が濃化したことが考えられる。高濃度の $\mathrm{Cl}^{-}$は鉄 の不働態被膜の形成を阻害することが知られており, MPA による鉄腐食では，地鉄と接する部分に $\mathrm{Cl}^{-}$が濃化 することで鉄腐食を促進している可能性が考えられる。 なお, 腐食生成物の地鉄と接しない上層に検出された $\mathrm{Fe}$, $\mathrm{O}, \mathrm{P}, \mathrm{Mg}$ に関しては，X 線回折によって構成成分を同 定することはできなかった。

MPA と SRB が共存した場合には, MPA 単独の場合よ りも激しく純鉄を腐食した。腐食形態は MPA 単独の場 合と同様にほぼ均一な全面腐食であった（Fig. 1(d)). SEM-EDSにより，腐食生成物には，Fe，C，O，S が検出 された (Fig. 5). Fe, C, O は，腐食生成物の地鉄と接す る部分に検出された。腐食生成物の X 線回折により, $\mathrm{FeCO}_{3}$ が検出された (Table 1)。したがって，SEM-EDS で検出された $\mathrm{Fe}, \mathrm{C}, \mathrm{O}$ は, $\mathrm{FeCO}_{3}$ に由来するものと考 えられる。また， S は腐食生成物表面の腐食試験液と接 する位置に被膜状に濃化して検出された（Fig. 5)．S が 腐食試験液と接する表面で被膜状に濃化することは, SRB 単独による腐食の場合にも観察された (Fig. 3).

MPA を接種して腐食試験を開始した後， 1 週間後に $\mathrm{SRB}$ を接種して計 2 週間腐食試験した場合には，MPA
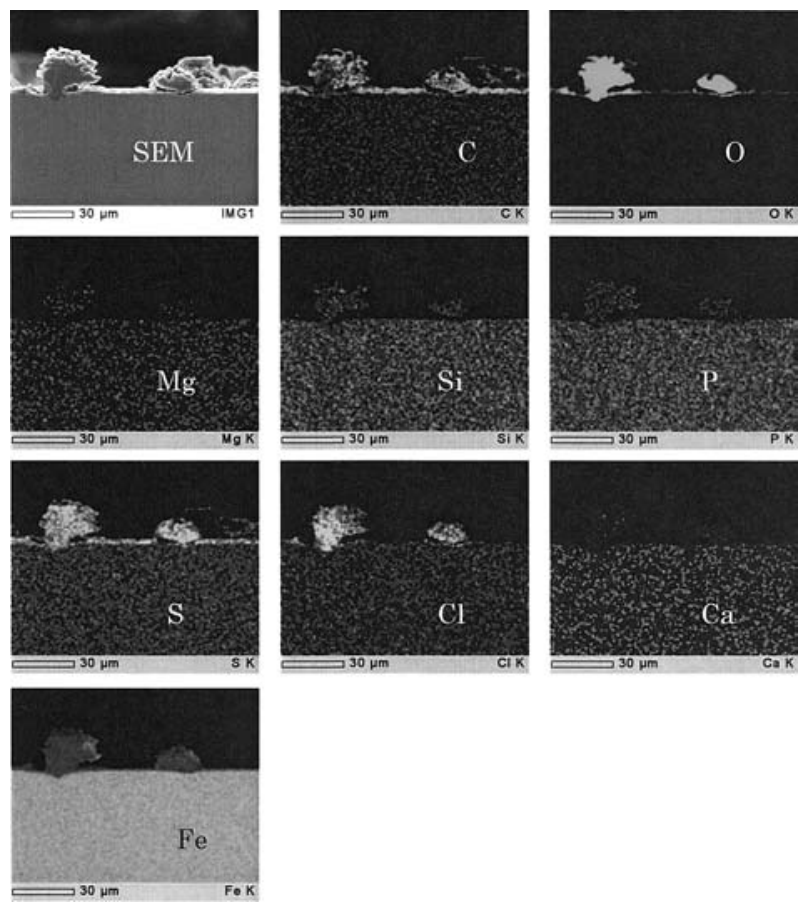

Fig. 3 Cross section image of iron coupon by SEM-EDS (SRB) 

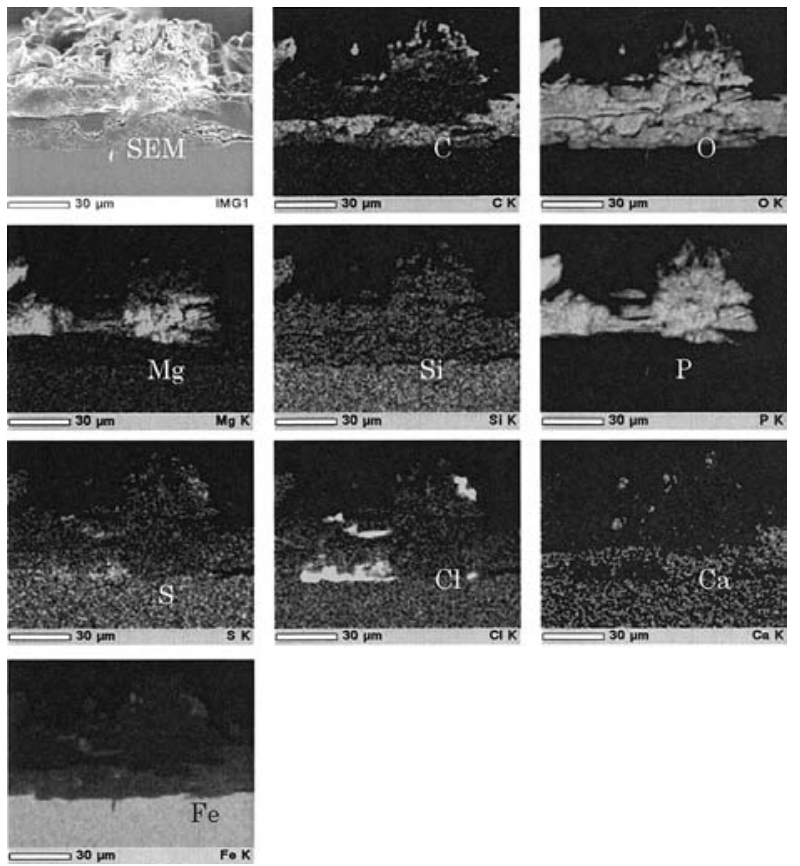

Fig. 4 Cross section image of iron coupon by SEM-EDS (MPA).
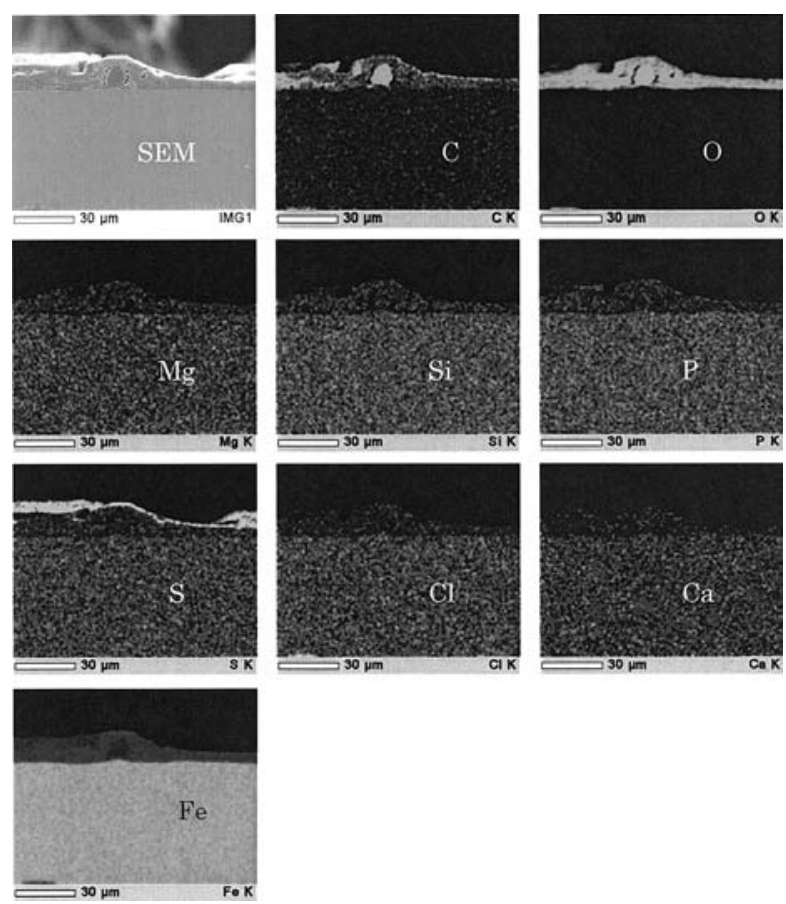

Fig. 5 Cross section image of iron coupon by SEM-EDS (MPA+ $\mathrm{SRB})$.

と SRB が共存した場合の腐食と MPA 単独による腐食の 中間程度の腐食が起こった (Fig. 1(e)). SEM-EDS によ り, 腐食生成物には $\mathrm{FeCO}_{3}$ と考えられる $\mathrm{Fe}, \mathrm{C}, \mathrm{O}$ を含 む層が観察された (Fig. 6).ささらに，この $\mathrm{FeCO}_{3}$ と考え られる腐食生成物層と地鉄の境界部分には $\mathrm{Cl}^{-}$の濃化が 観察された. $\mathrm{FeCO}_{3}$ からなる腐食生成物層と地鉄の境界 部分に $\mathrm{Cl}^{-}$が濃化することは, MPA 単独による腐食でも 観察されている (Fig. 4).

腐食生成物として $\mathrm{FeCO}_{3}$ が生成するメカニズムは, 鉄
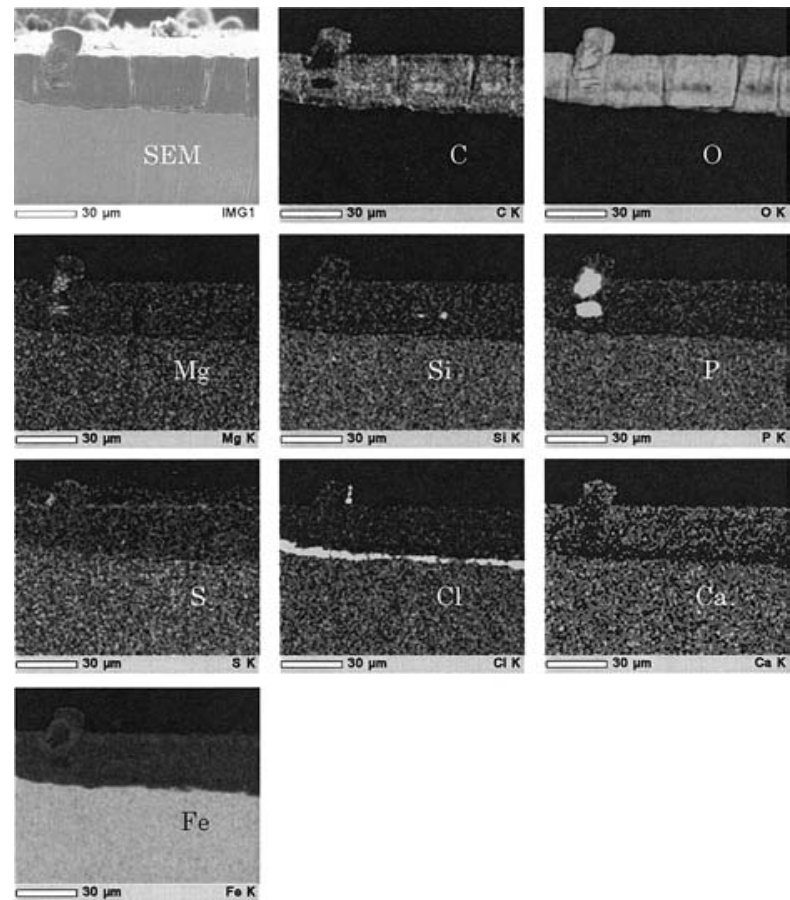

Fig. 6 Cross section image of iron coupon by SEM-EDS (MPA+ SRB (SRB were inoculated one week later.)).

Table 1 Substances detected by XRD.

\begin{tabular}{c|c}
\hline & Substances detected XRD \\
\hline Control & $\mathrm{Fe}$ \\
\hline SRB & $\mathrm{Fe}$ \\
\hline MPA & $\mathrm{Fe}, \mathrm{FeCO}_{3}$ \\
\hline MPA+SRB & $\mathrm{Fe}, \mathrm{FeCO}_{3}$ \\
\hline
\end{tabular}

の腐食によるアノード反応で溶出した $\mathrm{Fe}^{2+}$ が腐食試験液 中の $\mathrm{HCO}_{3}{ }^{-}$と以下のように反応して, $\mathrm{FeCO}_{3}$ が生成す ることが考えられる。

$$
\mathrm{Fe}^{2+}+\mathrm{HCO}_{3}^{-} \rightarrow \mathrm{FeCO}_{3}+\mathrm{H}^{+}
$$

また, $\mathrm{Cl}^{-}$が地鉄と腐食生成物の境界部分に濃化するメ カニズムは以下のように考えられる．鉄のアノード反応 部の近傍では, 溶出した $\mathrm{Fe}^{2+}$ が水和する反応,

$\mathrm{Fe}^{2+}+2 \mathrm{H}_{2} \mathrm{O} \rightarrow \mathrm{Fe}(\mathrm{OH})_{2}+2 \mathrm{H}^{+}$

あるいは，溶出した $\mathrm{Fe}^{2+}$ が $\mathrm{HCO}_{3}{ }^{-}$と結合して $\mathrm{FeCO}_{3}$ に なる反応

$$
\mathrm{Fe}^{2+}+\mathrm{HCO}_{3}^{-} \rightarrow \mathrm{FeCO}_{3}+\mathrm{H}^{+}
$$

により局所的に酸性化することが考えられる. 塩化物イ オン $\mathrm{Cl}^{-}$は, $\mathrm{SO}_{4}{ }^{2-}$ など海水に含まれる他の陰イオンと比 べて，腐食生成物の欠陥部などをとおして移動しやすい ことが考えられるため，アノード反応部近傍で発生する $\mathrm{H}^{+}$と電気的中性条件を満たすように, $\mathrm{Cl}^{-}$が地鉄と腐食 生成物の境界部分に濃化したことが考えられる。

Fig. 1(a)から (e)の SEM 断面観察写真より, 腐食生成 物を除いた地鉄部分の残存板厚を 3 力所で測って, 1 年 間あたりの板厚減量を腐食速度として計算した。結果を Table 2 に示す. 嫌気性条件 $\left(\mathrm{N}_{2}(80 \%)+\mathrm{CO}_{2}(20 \%)\right)$ に おいて, SRB 単独による腐食試験では, 表層が黒色の硫 化鉄を含むと考えられる薄い被膜で覆われ, 腐食は軽微 
Table 2 Corrosion Rate of iron under $\mathrm{N}_{2}(80 \%)+\mathrm{CO}_{2}(20 \%)$ (at $\left.22^{\circ} \mathrm{C}\right)$.

\begin{tabular}{l|c|c|c|c|c}
\hline & Control & SRB & MPA & MPA+SRB & $\begin{array}{c}\text { MPA+SRB } \\
\text { (SRB were } \\
\text { inoculated } \\
\text { one week later) }\end{array}$ \\
\hline $\begin{array}{l}\text { Corrosion Rate } \\
\text { (mm/year) }\end{array}$ & $0.13 \pm 0.00$ & $0.05 \pm 0.02$ & $0.59 \pm 0.03$ & $1.36 \pm 0.12$ & $0.66 \pm 0.12$ \\
\hline
\end{tabular}

Table $3 \mathrm{pH}$ in corrosion test medium.

\begin{tabular}{l|c|c|c|c|c}
\hline & Control & SRB & MPA & MPA+SRB & $\begin{array}{c}\text { MPA+SRB } \\
\text { (SRB were } \\
\text { inoculated } \\
\text { one week later) }\end{array}$ \\
\hline $\begin{array}{l}\text { After anaerobic corrosion } \\
\text { test (two weeks) }\end{array}$ & 7.1 & 7.1 & 7.1 & 7.3 & 7.2 \\
\hline $\begin{array}{l}\text { After aerobic corrosion } \\
\text { test (two weeks) } \\
\text { subsequent to anaerobic } \\
\text { corrosion test (two weeks) }\end{array}$ & 7.2 & 7.1 & 7.1 & 7.3 & 7.2 \\
\hline
\end{tabular}

であったが, SEM 断面観察写真をもとに腐食速度は 0.05 $\mathrm{mm} /$ year と計算された。 これに対して, MPA 単独によ る腐食速度は $0.59 \mathrm{~mm} /$ yearであった。ささらに, MPA と $\mathrm{SRB}$ が共存すると腐食速度は $1.36 \mathrm{~mm} /$ year となり, MPA 単独の場合と比較して約 2.3 倍腐食が促進されたこ とがわかった。また，MPAによる腐食試験の開始後，1 週間後に SRB を追加添加した場合の腐食速度は 0.66 $\mathrm{mm} /$ year となり, MPA と SRB 共存による腐食と MPA 単独による腐食の中間の腐食速度となった。

嫌気性条件での腐食試験後の試験液の pH を Table 3 の上段に示した. Hepes 緩衝液の効果により, 試験液の $\mathrm{pH}$ は 7.1 から 7.3 の範囲にあり, 腐食試験後の試験液の $\mathrm{pH}$ に大きな違いは見られなかった。腐食が激しかった， $\mathrm{MPA}$ と SRB が共存する場合は, 腐食試験液の $\mathrm{pH}$ が 7.3 と若干高めの值となった。

嫌気性環境において鉄腐食に伴うカソード反応

$$
2 \mathrm{H}_{2} \mathrm{O}+2 \mathrm{e}^{-} \rightarrow 2[\mathrm{H}]+2 \mathrm{OH}^{-} \rightarrow \mathrm{H}_{2}+2 \mathrm{OH}^{-}
$$

の促進や，鉄を電子供与体， $\mathrm{CO}_{2}$ を電子受容体かつ炭素 源として利用可能な MPA によるメタン生成反応

$$
4 \mathrm{Fe}+\mathrm{CO}_{2}+6 \mathrm{H}_{2} \mathrm{O} \rightarrow \mathrm{CH}_{4}+4 \mathrm{Fe}^{2+}+8 \mathrm{OH}^{-}
$$

の促進などがアルカリ化の原因として考えられる.

3.2 嫌気性条件 $\left(\mathrm{N}_{2}(80 \%)+\mathrm{CO}_{2}(20 \%)\right)$ での腐食に 引き続く好気性条件 (空気下) での腐食試験の結果

2 週間嫌気性条件 $\left(\mathrm{N}_{2}(80 \%)+\mathrm{CO}_{2}(20 \%)\right)$ での腐食試 験に引き続き， 2 週間好気性条件（空気下）で腐食試験 を行った試験片の断面を SEM 観察した結果を Fig. 7 (a) か ら (e)に示した。無菌の場合, 空気にさらした後，孔食状 の局部腐食が観察された (Fig. 7 (a) ; 白線で囲んだ部位). SEM-EDS による解析結果（Fig. 8）により，空気にさら した後の腐食生成物には主に Fe と O が検出されること から，オキシ水酸化鉄 $(\mathrm{FeOOH})$ が生成したものと考え られる。

$\mathrm{SRB}$ 単独の場合，嫌気性条件 $\left(\mathrm{N}_{2}(80 \%)+\mathrm{CO}_{2}(20 \%)\right)$ から好気性条件（空気下）に変えても, 腐食促進は観察 されなかった．嫌気性条件の腐食試験で観察された硫化 鉄と考えられる S を含む腐食生成物表層の被膜（Fig. 3) は，好気性条件で試験を行った後の腐食生成物では消失

\section{した (Fig. 9).}

MPA 単独の場合，嫌気性条件 $\left(\mathrm{N}_{2}(80 \%)+\mathrm{CO}_{2}(20 \%)\right)$ では $\mathrm{FeCO}_{3}$ と考えられる $\mathrm{Fe}, \mathrm{C}, \mathrm{O}$ を多く含む腐食生成 物の層が地鉄表面に観察された（Fig. 4) が，好気性条件 (空気下) では，この層の上に $\mathrm{P}, \mathrm{O}, \mathrm{Fe}$ を含む層が観察 された (Fig. 10). 空気下では $\mathrm{CO}_{2}$ の供給が少なくなっ たため, $\mathrm{FeCO}_{3}$ に代わって，海水培地に含まれるリン酸 イオン $\mathrm{PO}_{4}{ }^{3-}$ と腐食で溶出した $\mathrm{Fe}^{2+}$ が結合して, リン酸 鉄 $\left(\mathrm{Fe}_{3}\left(\mathrm{PO}_{4}\right)_{2}\right)$ が形成された可能性が考えられる.

MPA と SRB が共存する場合, 好気性条件（空気下）

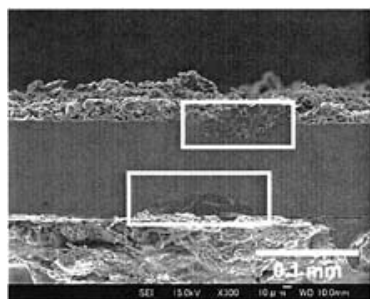

(a) Control

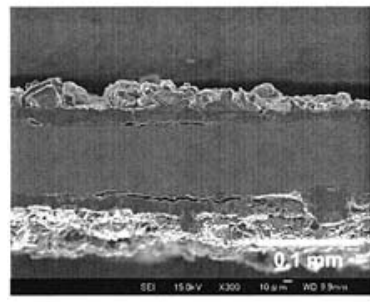

(c) MPA

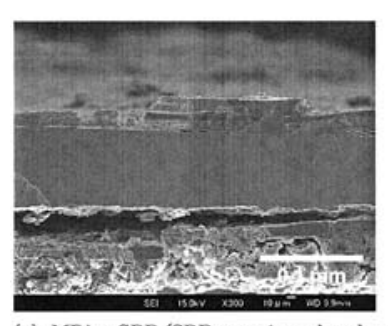

(e) MPA + SRB (SRB were inoculated one week later.)

Fig. 7 Cross Section Image of Iron Coupon by SEM (after air exposure for two weeks).

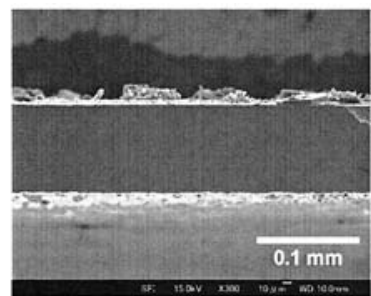

(b) SRB

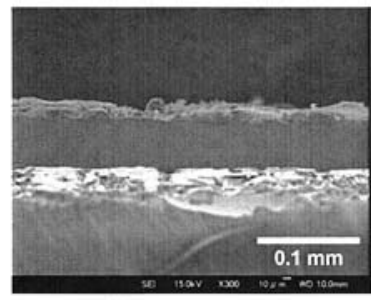

(d) $\mathrm{MPA}+\mathrm{SRB}$ 

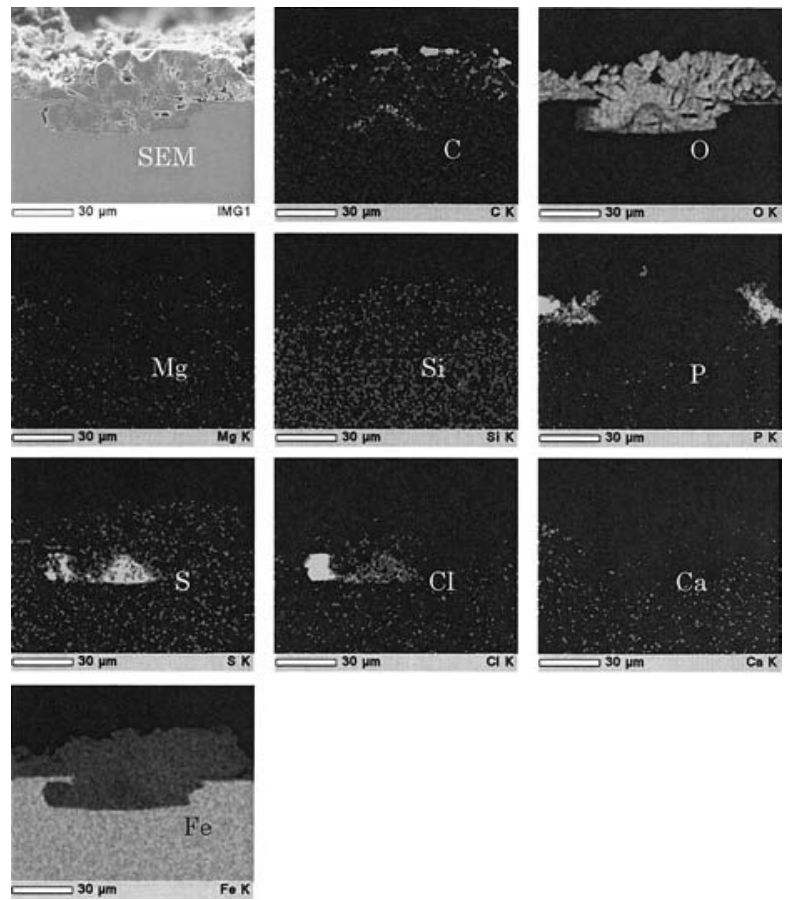

Fig. 8 Cross section image of iron coupon by SEM-EDS (Control) (after air exposure for two weeks).
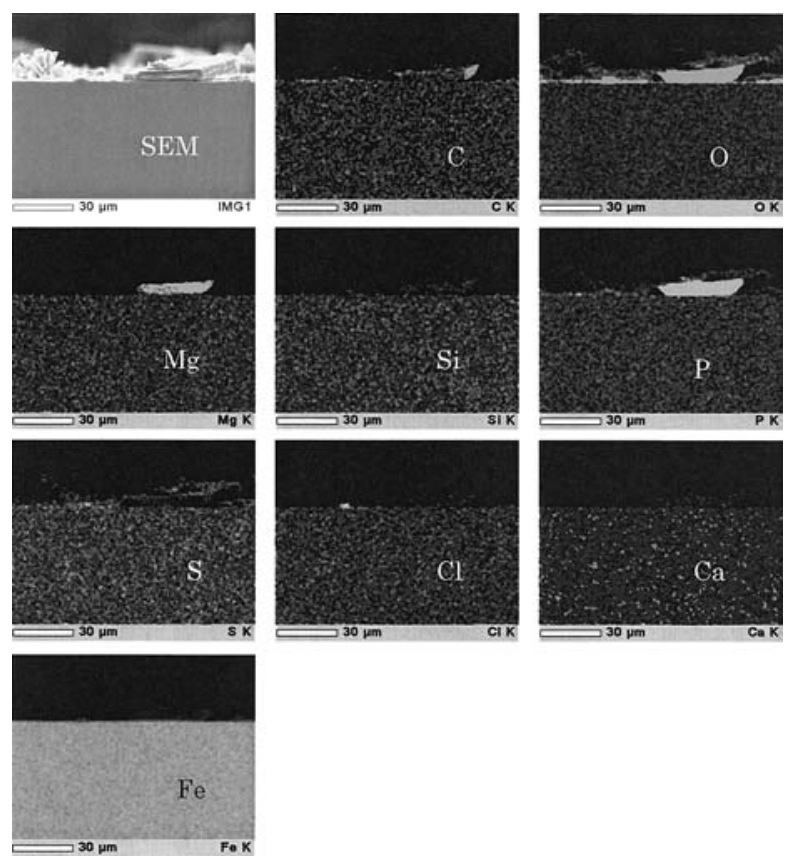

Fig. 9 Cross section image of iron coupon by SEM-EDS (SRB) (after air exposure for two weeks).

にしても $\mathrm{FeCO}_{3}$ を主要構成成分とすると考えられる腐食 生成物の層が地鉄の表面を覆ったままであった（Fig. 11).

MPA を接種した後, 1 週間後に SRB を接種した場合 も同様に，好気性条件（空気下）にしても表層に $\mathrm{FeCO}_{3}$ を主要構成成分とすると考えられる腐食生成物の層が観 察された。この腐食生成物の層と地鉄の境界部には $\mathrm{Cl}^{-}$ の濃化が観察された。（Fig. 12）

さて, 本研究では嫌気性条件 (2 週間) のみと, 嫌気
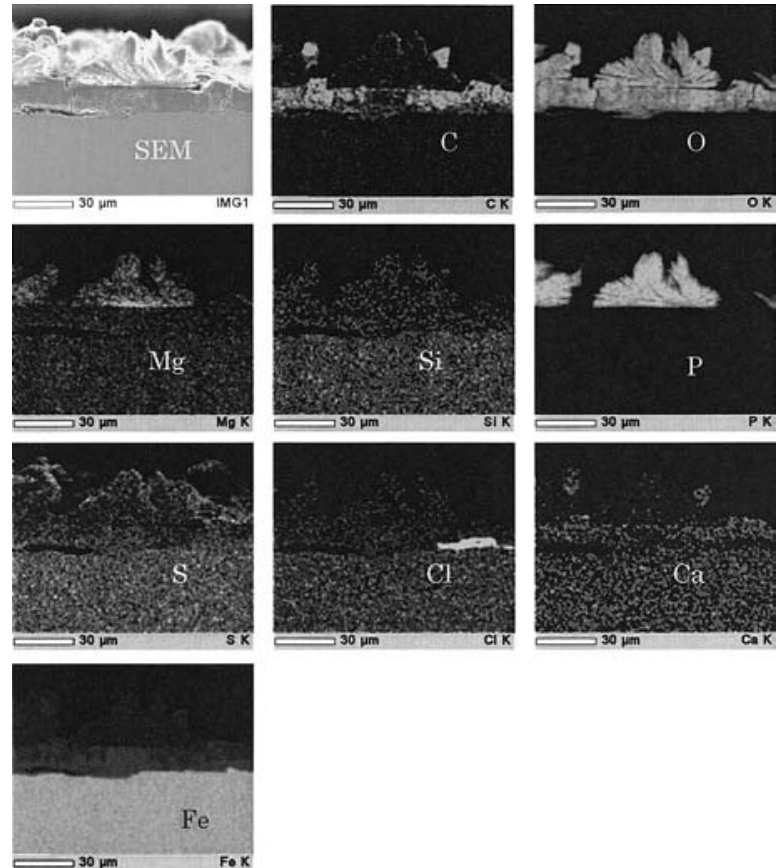

Fig. 10 Cross section image of iron coupon by SEM-EDS (MPA) (after air exposure for two weeks).
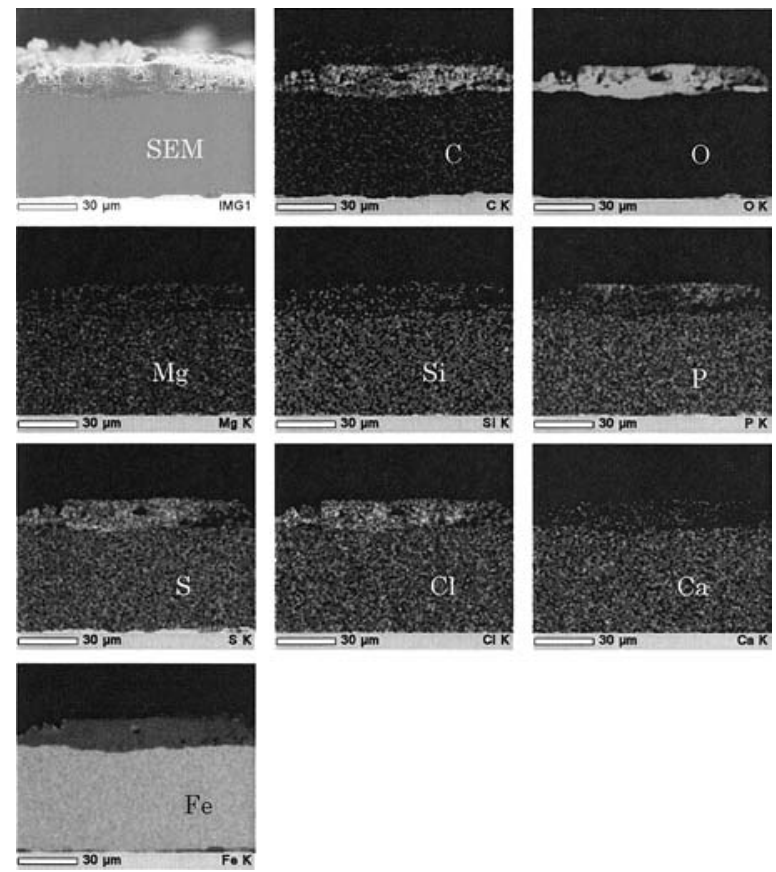

Fig. 11 Cross section image of iron coupon by SEM-EDS $(\mathrm{MPA}+\mathrm{SRB})$ (after air exposure for two weeks).

性条件 (2 週間) +好気性条件（2 週間）（計 4 週間）の 2 種類の腐食試験を同時に開始して並行して実施した。後 者の嫌気性条件（2 週間）+好気性条件（2 週間）（計 4 週間）の腐食試験において，嫌気性条件での腐食が，前 者の嫌気性条件（2 週間）のみの腐食試験と同様の腐食 速度で進行したものと仮定することにより，本腐食試験 の好気性条件 (空気下) での腐食速度を分けて計算する ことができる。結果を Table 4 に示した。比較のため, Table 2 に示した嫌気性条件における腐食速度と, Table 

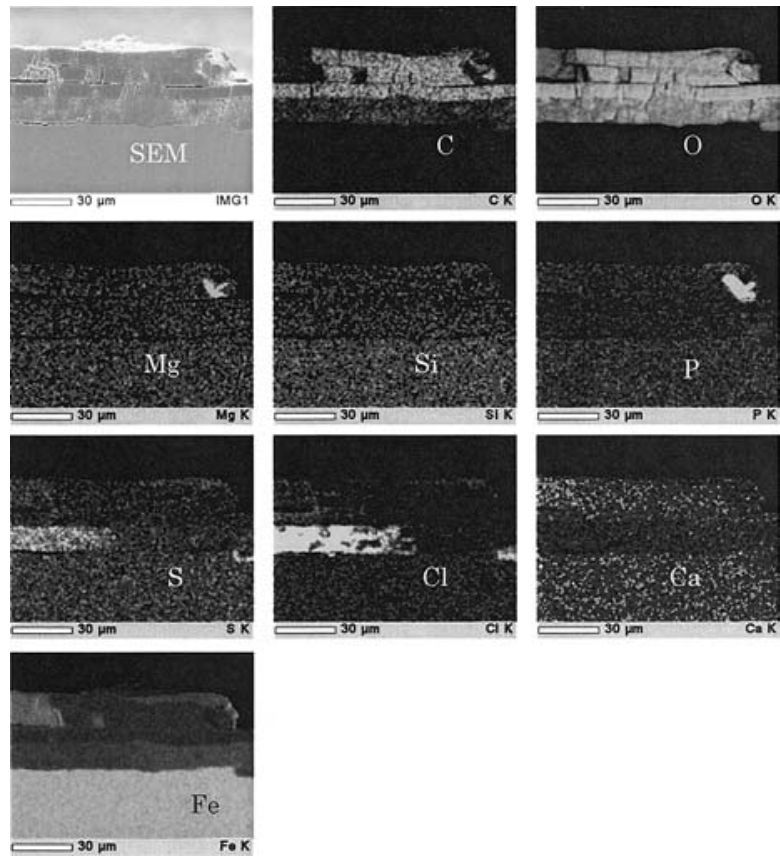

Fig. 12 Cross section image of iron coupon by SEM-EDS $(\mathrm{MPA}+\mathrm{SRB}$ (SRB were inoculated one week later.)) (after air exposure for two weeks).

4 に示した嫌気性条件に引き続く好気性条件（空気下） での腐食速度を Fig. 13 に棒グラフで示した。

嫌気性条件 $\left(\mathrm{N}_{2}(80 \%)+\mathrm{CO}_{2}(20 \%)\right)$ における腐食速度
は, MPA と SRB が共存する場合に最も高い值となった。 一方，好気性条件（空気下）での腐食速度は，0.12 $0.27 \mathrm{~mm} /$ year でほぼ同じレベルの值となり，MPA，SRB の存在有無による明確な違いは認められなかった。した がって，嫌気性微生物である MPA と SRB の共存による 激しい鉄腐食は，嫌気性条件 $\left(\mathrm{N}_{2}(80 \%)+\mathrm{CO}_{2}(20 \%)\right)$ で 進行しており, その後, 空気にさらされることによる腐 食影響は小さいことが明らかになった。

また, Table 5 には嫌気性条件 $\left(\mathrm{N}_{2}(80 \%)+\mathrm{CO}_{2}(20 \%)\right)$ と好気性条件 (空気下) での計 4 週間の腐食試験が終了 した後の試験液の全鉄濃度を示した.MPA と SRB が共 存した場合, MPA 単独の場合, 試験液の全鉄濃度はそ れぞれ $2380 \mathrm{mg} / \mathrm{L}, 774 \mathrm{mg} / \mathrm{L}$ であたのに対して，無菌 の場合, SRB 単独の場合, 試験液の全鉄濃度はそれぞれ $83 \mathrm{mg} / \mathrm{L}, 85 \mathrm{mg} / \mathrm{L}$ であった.

腐食試験液中の全鉄は，試験片表面の腐食生成物に移 行した鉄分を除けば，腐食により試験片から溶出した鉄 分と考えることができる．そこで，Table 5 の試験液の全 鉄濃度から試験液（体積 $20 \mathrm{~mL}$ ) に移行した鉄分の全量 を計算して, 結果を Table 6 の 2 段めに記した。例えば, MPA と SRB が共存した場合, 計 4 週間の腐食試験で $47.6 \mathrm{mg}$ の鉄分が試験片から試験液に移行した計算とな る. 本試験で用いた純鉄試験片の形状は $10 \times 10 \times 0.108$ $\mathrm{mm}$ であり，鉄の密度は $7.86 \mathrm{~g} / \mathrm{cm}^{3}$ のため, 試験片の初 期重量は $84.9 \mathrm{mg}$ となる. 試験片の初期重量から腐食に より試験液に移行した鉄分の重量を差し引いた重量が, 腐食試験後も試験片に残存している鉄の重量と考えられ

Table 4 Corrosion Rate of iron under air $\left(\right.$ at $\left.22^{\circ} \mathrm{C}\right)$.

\begin{tabular}{l|c|c|c|c|c}
\hline & Control & SRB & MPA & MPA+SRB & $\begin{array}{c}\text { MPA+SRB } \\
\text { (SRB were } \\
\text { inoculated } \\
\text { one week later) }\end{array}$ \\
\hline $\begin{array}{l}\text { Corrosion Rate } \\
\text { (mm/year) }\end{array}$ & $0.16 \pm 0.18$ & $0.23 \pm 0.02$ & $0.27 \pm 0.02$ & $0.17 \pm 0.02$ & $0.12 \pm 0.09$ \\
\hline
\end{tabular}

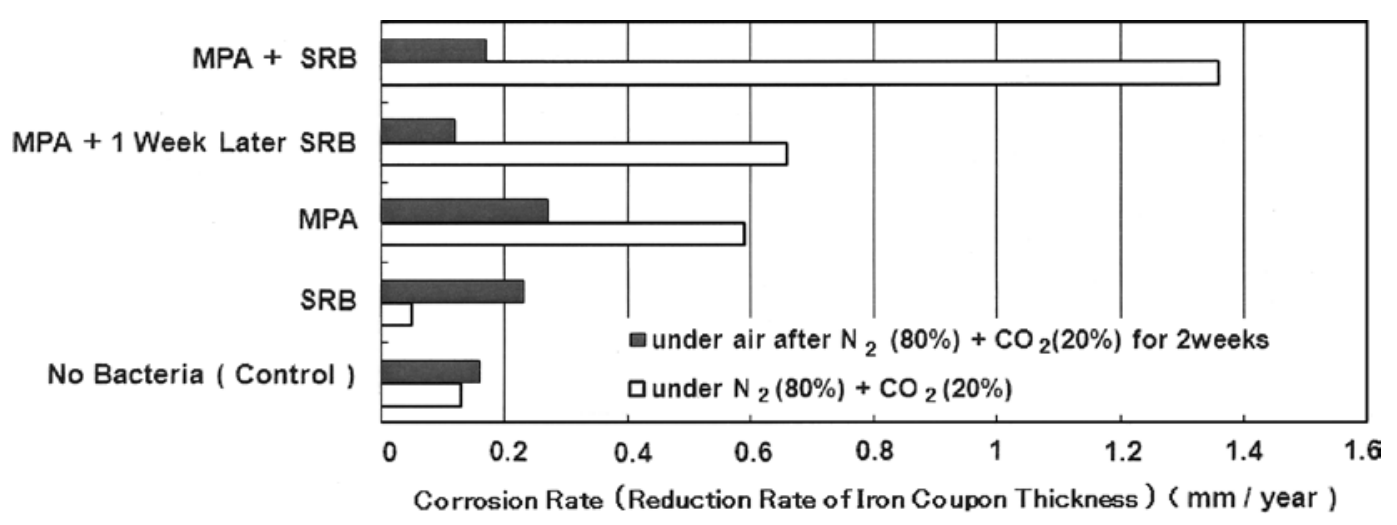

Fig. 13 Corrosion rate of iron coupon under anaerobic $\left(\mathrm{N}_{2}(80 \%)+\mathrm{CO}_{2}(20 \%)\right)$ and continuous aerobic (air) conditions.

Table 5 Total-Fe in the corrosion test medium after anaerobic and aerobic corrosion test.

\begin{tabular}{c|c|c|c|c|c}
\hline & Control & SRB & MPA & MPA+SRB & $\begin{array}{c}\text { MPA+SRB } \\
\text { (SRB were } \\
\text { inoculated } \\
\text { one week later) }\end{array}$ \\
\hline Total-Fe (mg/L) & 83 & 85 & 774 & 2380 & 1610 \\
\hline
\end{tabular}


Table 6 Total-Fe in the corrosion test medium, Estimated total-Fe remaining in the test coupon, Residual thickness of the test coupon and Residual thickness / initial thickness.

\begin{tabular}{l|c|c|c|c|c}
\hline & Control & SRB & MPA & MPA+SRB & $\begin{array}{c}\text { MPA+SRB } \\
\text { (SRB were inoculated } \\
\text { one week later) }\end{array}$ \\
\hline $\begin{array}{l}\text { Total-Fe in the } \\
\text { corrosion test } \\
\text { medium (mg) }\end{array}$ & 1.7 & 1.7 & 15.5 & 47.6 & 32.2 \\
\hline $\begin{array}{l}\text { Estimated total-Fe } \\
\text { remaining in the } \\
\text { test coupon (\%) }\end{array}$ & 98 & 98 & 82 & 44 & 62 \\
\hline $\begin{array}{l}\text { Residual thickness } \\
\text { of the test coupon } \\
(\mu \mathrm{m})\end{array}$ & 96.8 & 97.3 & 75.3 & 49.5 & 77.9 \\
\hline $\begin{array}{l}\text { Residual thickness/ } \\
\text { initial thickness (\%) }\end{array}$ & 90 & 90 & 70 & 46 & 72 \\
\hline
\end{tabular}

Table 7 ORP in corrosion test medium $\left(\mathrm{mV}_{\mathrm{SSE}}\right)$.

\begin{tabular}{l|c|c|c|c|c}
\hline & Control & SRB & MPA & MPA+SRB & $\begin{array}{c}\text { MPA+SRB } \\
\text { (SRB were inoculated } \\
\text { one week later) }\end{array}$ \\
\hline $\begin{array}{l}\text { After aerobic } \\
\text { condition }\end{array}$ & +26 & +25 & +22 & -113 & -25 \\
\hline
\end{tabular}

る.この試験片に残存している鉄の重量を試験片の初期 重量で割った值 $(\%)$ を Table 6 の 3 段めに示した。例え ば，MPA と SRB が共存した試験条件では, 嫌気性条件 と好気性条件合わせて 4 週間の腐食試験終了後に初期重 量と比較して $44 \%$ の鉄が試験片に残存している計算とな る.

一方，均一な全面腐食を仮定した場合，試験片の残存 板厚と，試験液に移行せず試験片に残存している鉄の量 は比例することになる，そこで，計 4 週間の腐食試験後 にSEM 断面観察写真から測定された試験片の残存板厚 を Table 6 の 4 段めに示した. この残存板厚の初期板厚 $(108 \mu \mathrm{m})$ に対する割合を Table 6 の 5 段めに示した.

例えば，MPA と SRB が共存する場合，Table 6 の 3 段 めに示したように，試験液の全鉄濃度の測定結果から， 44\%の鉄分が試験片に残存しているものと計算された. 一方, Table 6 の 5 段めに示したように, 試験片板厚の測 定結果から，初期板厚に対して $46 \%$ 残存板厚が計算さ れた。両方の值はほほ類似の值となった，他の試験条件 では, 両者の值は若干異なる值となったが, 本研究で示 した MPA と SRB の共存による純鉄試験片の腐食促進作 用は，均一な全面腐食を仮定した板厚測定に基づく腐食 速度の結果と, 試験液に溶出した全鉄の濃度測定の結果 の両方から裏付けられることが明らかになった。

MPA と SRB が共存する場合の腐食生成物の主要成分 は, MPA 単独による腐食生成物と同様に炭酸鉄 $\left(\mathrm{FeCO}_{3}\right)$ であったことから, MPA と SRB が共存する場 合の鉄腐食で主要な役割を担っているのは, SRB ではな く, MPA と考えられる。また， $\mathrm{Cl}^{-} の$ 濃化が腐食生成物 と地鉄の間に観察された。したがって, 本研究の MPA による腐食, MPA と SRB の共存による腐食では, $\mathrm{FeCO}_{3}$ を形成するのに十分量の $\mathrm{CO}_{2}$ と, $\mathrm{Cl}^{-}$の濃化に必 要な $\mathrm{Cl}^{-}$の存在が, 腐食の促進に関与している可能性が 考えられる. SRB が共存することで MPA の腐食能力が
増強されるメカニズムは今のところ分かっていない。 $\mathrm{SRB}$ が発生する $\mathrm{HS}^{-}$は強力な還元剤であるため, 酸化還 元電位 (ORP) を低下させる作用がある．低い ORP の環 境を好む MPA に適した環境が SRB と共存することで形 成された可能性が考えられる. Table 7 は嫌気性条件 $\left(\mathrm{N}_{2}(80 \%)+\mathrm{CO}_{2}(20 \%)\right)$ での 2 週間の腐食試験の後, 2 週間好気性条件（空気下）で腐食試験した後の試験液の ORP の測定結果であるが，空気にさらした後であるにも 関わらず，MPA と SRB が共存した場合にはー $113 \mathrm{mV}_{\mathrm{SSE}}$ と最も低い ORP 值であった. したがって, SRB と共存 することで, MPA 単独の場合と比べて MPAに適した低 いORB の環境が実現されていた可能性が考えられる.

本研究では, 金属鉄を電子供与体とする条件で培養可 能な MPA と SRB を用いた。これらの微生物がどのよう に鉄から電子を受け取るか，そのメカニズムは今のとこ ろ不明である. 本研究で使用した MPA, SRB ともに $\mathrm{H}_{2}$ を電子供与体とする条件でも培養可能であるため, 鉄の 腐食に伴うカソード反応 $\left(2 \mathrm{H}_{2} \mathrm{O}+2 \mathrm{e}^{-} \rightarrow 2[\mathrm{H}]+2 \mathrm{OH}^{-}\right.$ $\rightarrow \mathrm{H}_{2}+2 \mathrm{OH}^{-}$) で発生する水素を電子供与体として利用 している可能性や，Uchiyama ら ${ }^{2)}$ が推定しているよう に，直接金属鉄に接触して電子を受け取る可能性なども 考えられるが，今のところ詳細は不明である.

また, 本研究で用いた MPA と SRB は金属鉄を電子供 与体として利用可能な菌体であるため, 有機酸など有機 物を電子供与体として利用する一般的な微生物と比べる と，特殊な菌体を選んで腐食試験を行ったことになる。 有機酸など有機物を電子供与体として利用する他の微生 物がいる場合に, 本研究で用いた MPA と SRB の共存に よる腐食促進が起こるか否かについては, 今後の課題で ある。 
4. 結

嫌気性条件 $\left(\mathrm{N}_{2}(80 \%)+\mathrm{CO}_{2}(20 \%)\right)$ の海水培地中にお いて，金属鉄を電子供与体として， $\mathrm{CO}_{2}$ を電子受容体か つ炭素源として利用可能な MPA は, 純鉄試験片の腐食 を促進した。主要な腐食生成物は $\mathrm{FeCO}_{3}$ であった。この MPA が, 同様に金属鉄を電子供与体として利用可能な $\mathrm{SRB}$ と共存することで, MPA 単独の場合よりも腐食速 度がさらに約 2.3 倍高い值となった. MPA と SRB が共 存する場合の腐食生成物も, MPA 単独による腐食生成 物と同様に $\mathrm{FeCO}_{3}$ であった。

嫌気性条件 $\left(\mathrm{N}_{2}(80 \%)+\mathrm{CO}_{2}(20 \%)\right)$ と，引き続く好気 性条件（空気下）での腐食速度を比較した結果, MPA と SRB が共存する場合, あるいは MPA 単独の場合の腐 食は，主に嫌気性条件 $\left(\mathrm{N}_{2}(80 \%)+\mathrm{CO}_{2}(20 \%)\right)$ で進行し ており，引き続き空気にさらすことによる腐食影響は小 さいことが明らかになった。

油井など高濃度の $\mathrm{CO}_{2}$ と $\mathrm{Cl}^{-}$が存在するような嫌気性 腐食環境においては，本研究で腐食試験に使用したよう な金属鉄を電子供与体として, $\mathrm{CO}_{2}$ を電子受容体や炭素 源として利用可能な MPA と SRB が共存している可能性
も想定される. MPA 単独, SRB 単独による腐食のみな らず，MPA と SRB の共存による腐食についても十分留 意すべきと考えられる。

本研究はNEDO「微生物を利用した石油の環境安全対 策に関する調査」の一環として実施した。

\section{参 考 文 献}

1) K. Ito, T. Uchiyama, T. Iino, K. Mori, S. Wakai, H. Tsurumaru, O. Miki and S. Harayama, Zairyo-to-Kankyo, 59, 298 (2010).

2) T. Uchiyama, K. Ito, K. Mori, H. Tsurumaru and S. Harayama, Appl. Environ. Microbiol., 76, 1783 (2010).

3) J. A. Hardy and J. L. Bown, Corrosion, 40, 650 (1984).

4) T. R. Jack, M. Wilmot, J. Stockdate, G. Van Boven, R. G. Worthingham and R. L. Sutherby, Corrosion, 54, 246 (1998).

5) F. Widdel and F. Bak, Gram-negative mesophilic sulfatereducing bacteria. In The prokaryotes. 2nd vol. IV, Edited by A. Balows, H. G. Trüper, M. Dworkin, W. Harder and K. H. Schleifer. New York, Springer-Verlag. p.3352-p.3378 (1992).

6) H. T. Dinh, J. Kuever, M. Mussmann, A. W. Hassel, M. Stratmann and F. Widdel, Nature, 427, 829 (2004).

(Manuscript received March 2, 2011; in final form May 19, 2011)

\section{要旨}

嫌気性条件 $\left(\mathrm{N}_{2}(80 \%)+\mathrm{CO}_{2}(20 \%)\right)$ の海水培地に扔いて, 金属鉄を電子供与体として, $\mathrm{CO}_{2}$ を電子受 容体かつ炭素源として利用可能な MPA は, 純鉄試験片を腐食した. 主要な腐食生成物は $\mathrm{FeCO}_{3}$ であった。 この MPA が，同様に金属鉄を電子供与体として利用可能な SRB と共存することで, MPA 単独の場合よ りも腐食が約 2.3 倍促進されることが明らかになった。 MPA と SRB が共存する場合の腐食生成物も, $\mathrm{MPA}$ 単独による腐食生成物と同様に $\mathrm{FeCO}_{3}$ であった。

また，嫌気性条件 $\left(\mathrm{N}_{2}(80 \%)+\mathrm{CO}_{2}(20 \%)\right)$ での腐食速度と，引き続く好気性条件（空気下）での腐食 速度を比較した結果, MPA 単独, あるいは, MPA と SRB が共存する場合の腐食速度は, 嫌気性条件 $\left(\mathrm{N}_{2}(80 \%)+\mathrm{CO}_{2}(20 \%)\right)$ の方が高い值となった.

本研究で腐食試験に使用した MPA と SRB は同一の原油タンクのスラッジから単離されたものである. 油井など高濃度の $\mathrm{CO}_{2}$ と $\mathrm{Cl}^{-}$が存在する実際の嫌気性腐食環境に扔いては，金属鉄を電子供与体として， $\mathrm{CO}_{2}$ を電子受容体や炭素源として利用可能な MPA と同じく金属鉄を電子供与体として利用可能な SRB が 共存している可能性も想定される。したがって, 金属鉄を電子供与体として利用可能な MPA と SRB の共 存による微生物腐食に対しても留意すべきと考えられる.

キーワード メタン生成古細菌（MPA）, 硫酸塩還元菌（SRB）, 鉄, 微生物腐食, 嫌気性微生物, 原 油, 海水, 炭酸鉄 